\title{
Journal of Political Science
}

(A Peer-Reviewed, Open Access Journal and Indexed in NepJOL) ISSN 2362-1273 (Print); ISSN 2773-8132 (Online)

Volume 21, Special Issue, August 2021 http://ejournals.pncampus.edu.np/ejournals/jps/

\section{Published by}

Department of Political Science, Prithvi Narayan Campus, TU, Pokhara, Nepal

Email: polsc@ pncampus.edu.np; URL: www.pncampus.edu.np

\section{Foucault's Dismissal of Ideology: A Critique}

\author{
Khagendra Prasai, PhD \\ Faculty of Social Sciences \& Education \\ Nepal Open University, Kathmandu
}

Corresponding Author: Khagendra Prasai, Email: khagendra@noc.edu.np

DOI: https://doi.org/10.3126/ips.v21i1.39289

Copyright 2021@ The Publisher and Author/s. The journal is licensed under a Creative Commons Attribution-ShareAlike 4.0 International License.

\section{(c) (i) ()}

Submitted 24 July 2021; Reviewed 25 July 2021; Accepted 28 July 2021; Published 20 Aug. 2021

\begin{abstract}
Foucault dismisses ideology as an object of investigation in understanding power relations for three important reasons bearing on his rejection of true-false distinction, dismissal of reference to subject and trivialization of ideology. This paper argues against Foucault's claim and shows that investigation of ideology constitutes an important task in understanding relation of domination - which is substantiated by demonstrating firstly that the true-false distinction is not only ontologically real but also morally warranted; and secondly that ideology is not merely a passive effect of infrastructure of an oppressive social system but is in reciprocal relation with it and therefore plays an indispensably important role in maintaining the system in general and the present-day capitalism in particular.
\end{abstract}

Keywords: Foucault, Marx \& Engels, Althusser, Marcuse, ideology, power relation

\section{Introduction}

In his celebrated essay 'Two Lectures' Foucault dismisses ideology as an object of investigation in power relations. He argues that thought major mechanisms of power could have been accompanied by ideological productions, what has occurred is not ideological but both much more and much less than ideology (Foucault 1976, 102). For him, it is rather "the production of effective instruments for the formation and accumulation of knowledge" such as "methods of observation, techniques of registration, procedures for investigation and 


\section{Foucault's Dismissal of Ideology: A Critique}

research, apparatuses of control" which evolve into "apparatuses of knowledge" which are not "ideological constructs" (Foucault 1976, 102). In another essay 'Truth and Power', Foucault further gives reasons for why the notion of ideology is not useful in understanding power which bear on true-false distinction, reference to social subject and the position of ideology relative to its infrastructure (Foucault 1977, 118). Principally, Foucault targets his arguments against the importance given to ideology as instrument of oppression by classical Marxism and critical theories. In this context, this paper is an attempt to examine Foucault's argument and demonstrate that ideology constitutes an important component of power relation in a capitalist society. To this end, this paper is divided into four sections: the second section examines Foucault's dismissal of true-false distinction and accordingly argues why the notion of truth is important in understanding and challenging an oppressive social formation; the third section makes a case for why ideology occupies important and decisive position in a capitalist society; the fourth section sums up the paper.

\section{Ideology and True-false Distinction}

We have already mentioned that one reason for Foucault's rejection of has to do with truth. Foucault argues that ideology "always stands in virtual opposition to something else which is supposed to count as truth" (Foucault, 1977, p. 118). But he believes that "problem does not consist in drawing line between that in a discourse which falls under category of scientificity or truth, and which comes under some other category, but in seeing historically how effects of truth are produced within discourses which in themselves are neither true nor false" (Foucault, 1977, p. 118). By truth, Foucault does not mean "the ensemble of truths which are to be discovered and accepted" but rather "ensemble of rules according to which the true and false are separated and specific effects of power attached to the true, it being understood also that it's not a matter of a battle 'on behalf' of truth, but a battle about the status of truth and the economic and political role it plays" (Foucault, 1977, p. 132). Foucault does not see it necessary to see political problems "in terms of 'science' and 'ideology" rather in terms of 'truth' and 'power"' (Foucault, 1977, p. 132). These ideas led him to believe that "the problem is not changing people's consciousness - or what's in their head-but political, economic, institutional regime of the production of truth" (Foucault, 1977, p. 133).

In his analysis of truth, Foucault, unambiguously, rejects true-false distinction. He does not draw a line between truth and untruth, nor does he take truth to be discovered and accepted. Foucault champions anti-representationalist or even deflationist view of truth view of truth and accordingly rules out the notion of objectively existing reality understandable and representable by a subject objectively. Therefore, as an anti representationalist, Foucault "raised doubts about ideology-critique insofar as its proponents, Marxian or otherwise, assumed a notion of truth as accurate understanding of the intrinsic nature of thingsincluding the intrinsic nature of man" (Kumar, 2005, p. 62).

Foucault's notion of truth defeats his own analysis and methodology. For instance, he sides with and stands for 'subjugated knowledge' which he hopes to bring into play by the genealogy and archeology. For this, doesn't Foucault need an objective and accurate account of subjugating and subjugated knowledge and how such subjugation came into effect? His dismissal of true-false distinction inevitably dismisses this possibility. His analysis and account of history of madness, homosexuality, suppression of prisoners etc., likewise, falls flat without true-false distinction. How could one talk about these issues or any other issue for that matter without their accurate representation? Doesn't his question 


\section{Foucault's Dismissal of Ideology: A Critique}

"is power reducible to economy?" require an accurate representation of reality or true-false distinction for it to be answered plausibly and accurately? Any method of investigation that is not based on true-false distinction requires us to accept all statement as true or even equally true. Such method leaves overwhelming room for opinions which are not or will not be subject to test and scrutiny, which in turn dismisses the need and usefulness of any method of investigation. What use is genealogy? What use is archeology?

Such anti-representationalist notion of truth has serious implication and consequence in moral and practical action. Formulation of project of liberation from any form of domination or suppression requires, in the first place, an accurate understanding of condition of domination and its mechanisms and functioning. To be ignorant of the true conditions is "to be unaware of the need to change them; and to lack knowledge as to how these conditions might be changed for better" (Detmer, 2003, p. 98). Likewise, "to mistake the false for true-is to be unable to effect the positive changes that are called for" (Detmer, 2003. p. 98).

All oppressive systems practice obscurantism to keep people ignorant of the real conditions and supply people those ideas and principles that are meant to justify oppression and all associated practices. "Immoral policies are propped up by lies and sustained by ignorance" (Detmer, 2003, p. 98). The oppressive nature and immorality of the system can be revealed only through true understanding of the real conditions which can be possible only through representationalist view and account of truth. Therefore, system of domination is always antagonistic to truth and concern for truth, no matter the pursuit is about physical or social world. Given this reactionary role of untruth or falsehood, ideology as falsification and distortion of reality has to be opposed and fought-for which, we need a clear-cut demarcation between what is true and what is false. Dismissing or undermining true-false distinction makes the matter worse and serves to strengthen system of domination. Therefore, truth is supremely important in our fight for justice against system of domination.

Foucault is bound to dismiss this argument as he is skeptical of Enlightenment project or any other emancipatory project, for that matter. But he is critical of 'regime of truth' and appeals intellectual to criticize "the political, economic, institutional regime of production of truth" (Foucault .1977, p. 133). He criticizes "disciplinary society", "coercive practices and subtle techniques" of control, "society of normalization" and recommends intellectual to "struggle against the forms of power that transform him into its object and instrument in the sphere of "knowledge," "truth," "consciousness", and "discourse"” (Foucault, 1972, p. 208). Foucault also intends to give due weight "to the fact of domination" (Foucault, 1976, p. 95). However, what he fails to see is that these criticism and recommendations are vacuous without true-false distinction. From moral and practical point of view too, his critique must be based on certain standard of good and bad, which, in turn, necessarily requires truth. For example, on what moral ground should one resist certain form of power? Critique and resistance of this form of power is possible only when one understands that the power and its effect are bad, which, in turn, is possible only when we take the power and its operation to be objectively true.

Does Foucault really dismiss the truth and its role in power relations? Surprisingly, despite his critique of ideology, Foucault talks of truth and its role in power relations. In his study of power, in general, and how of power, in particular, Foucault is concerned with rules of right, the effects of truth and power itself - triangle of "power, right and truth" (Foucault, 1976, p. 93). His interest in this triangular equation, as he puts, has to do with rules of right that are 


\section{Foucault's Dismissal of Ideology: A Critique}

"implemented by the relations of power in the production of discourse of truth" (Foucault, 1976, p. 93). In the meantime, he also mentions how truth is essential for exercise of power. He says; "In a society such as ours, but basically in any society, there are manifold relations of power which permeate, characterize and constitute the social body, and these relations of power cannot themselves be established, consolidated nor implemented without production, accumulation, circulation and functioning of discourse. There can be no possible exercise of power without a certain economy of discourses of truth which operates and through and on the basis of this association. We are subject to the production of truth through power and we cannot exercise power except through production of truth" (Foucault, 1976, p. 93).

From Foucault's pretension on truth and truth-power relations, two important observations must be made. Firstly, Foucault suggests that "'Truth' is linked is in a circular relation with systems of power which produces and sustains it, and to effects of power which it induces and which extend it"-which he calls "a 'regime' of truth" (Foucault, 1977, p. 133). Secondly, power does not produce or intend to produce objective truth but the truth that is necessary for the power to function, therefore, the entire process of production is dictated by rules of right in those power relations. Such notion of truth and its role in power relations is, undoubtedly, closer to position held by Marxists in their critique of ideology. In Marxists tradition, ideology is an important element to be subjected to scientific and moral criticism. Ideology presents falsified, distorted and illusory picture of reality as true and natural, and, thereby, contributes to maintaining a system in the interest of ruling class, which controls and regulates the production of ideas as truth. Foucault's thesis that power produces 'truth' which best serves the power implicates that there can be another kind of 'truth' that not only does not fit well into interest of power but also challenges power. How does this 'different' truth challenge power? How can intellectuals struggle, without the aid of freely produced truth, against power which feeds on and is sustained by the illusory and repressive 'truth'? How can such struggle be possible if "if truth isn't outside power, ... isn't the reward of free spirit, ... and is produced only by virtue of multiple forms of constraints"? (Foucault, 1977, p. 131). In their struggle, they indispensably need alternative truth which is nothing if objective truth. How could his own strategy of "counter-discourse" be initiated and put into effect? What does counter-discourse aim except at unmasking the power- produced truth and challenging it with scientifically produced truth?

Therefore, the initial and necessary step to be taken is to unmask the regime of truth and its product, truth itself and to simultaneously produce the truth which confronts the power and its allied truth and lays the foundation for alternative power system which would be just and non-dominating. His interest in production of truth and its use, on the one hand and dismissal of ideology as an object of investigation in power relation are inconsistent.

\section{Ideology: Position and Role}

One of the reasons Foucault gives for dismissing ideology as object of investigation has to do with his according ideology the "secondary position relative to something which functions as its infrastructure, as its material, economic determinant, etc." (Foucault 1976, 118). But, does ideology occupy merely the secondary position in the present-day capitalist world? This question must be resolved by accurate understanding and analysis of position and role of ideology in this system. If its position and role are marginal, insignificant and accidental, ruling it out will not make significant difference in the analysis of the system. But if it has material status and influential role, it cannot and should not be dismissed on any pretext whatsoever. In what follows, I will present some theories, claims and explanation 


\section{Foucault's Dismissal of Ideology: A Critique}

brought forward by Marxist or ideology-critique school of thought and tradition, which, if plausible will suffice, to prove wrong or beat Foucault's dismissal of ideology.

Let me start with Marx's notion and principle of economic base and superstructure which, in his own words, is "the guiding principle" of his studies. Marx states: "The totality of ... relations of production constitutes the economic structure of society, the real foundation, on which arises a legal and political superstructure and to which correspond definite forms of social consciousness. The mode of production of material life conditions the general process of social, political and intellectual life. It is not the consciousness of men that determines their existence, but their social existence that determines their consciousness" (1859). For Marx and Engels, "the production of ideas, of conceptions, of consciousness" and also the "mental production as expressed in the language of politics, laws, morality, religion, metaphysics ..." are based on the "material activity" and are "conditioned by a definite development of their productive forces" and, therefore, "consciousness is nothing other than "conscious existence, and the existence of men is their actual life-process" (1845). If consciousness or mental production has such material basis then why is ideology mystifying, falsifying and distorting? Why and how does ideology tend to misrepresent the reality? Marx and Engels argue; "if in all ideology men and their circumstances appear upside-down as in a camera obscura, this phenomenon arises just as much from their historical life-process as the inversion of objects on the retina does from their physical lifeprocess" (1845). The question that follows is: what does the historical life process entail? It entails, inter alia, how consciousness is produced in class society; who owns and controls the production of consciousness; and what roles it plays. The answer is compacted on the widely known statement: "The ideas of the ruling class are in every epoch the ruling ideas." In a class society, ruling class, by virtue of the fact that it has control over means of material production, has control, at the same time, over the means of mental production" and therefore "the ideas of those who lack the means of mental production are subject to it" (Marx \& Engels, 1845). Consequently, these "ideas are nothing more than the ideal expression of the dominant material relationships, the dominant material relationships grasped as ideas, ... the ideas of its dominance" (Marx \& Engels 1845). It takes us to the conclusion that ruling class, in addition to ruling, regulates "the production and distribution of the ideas of their age" (Marx \& Engels 1845). The subjection of the ruled to the ruling ideas also takes place through acceptance, in ignorance, of "false consciousness" produced and propagated as ruling ideology. "Ideology", for Engels, "is a process accomplished by the so-called thinker consciously, indeed, but with a false consciousness. The real motives impelling him remain unknown to him, otherwise it would not be an ideological process at all” (Engels, 1893).

Now let us ponder over what role ideology plays in a class society? Equally importantly, is ideology determined by economic base one-sidedly and remain passive as effect? It is true that ruling ideas, as they are ideas of ruling class, play an important role to maintain the domination of ruling class over the ruled class. The relationship between base and superstructure appears to be of paramount concern here, which is widely misconceived to be one-way, i.e., the base begetting the superstructure. Engels (1894) clarifies: "Political, juridical, philosophical, religious, literary, artistic, etc., development is based on economic development. All these react upon one another and also upon the economic base." It is not that the economic position is the cause and alone active, while everything else only has a passive effect. There is, rather, interaction on the basis of the economic necessity, which ultimately always asserts itself." 


\section{Foucault's Dismissal of Ideology: A Critique}

The classical Marxist position on the status and role of ideology, thus, can be summed as follows: Firstly, ideology as definite form of consciousness depends, for its existence and development, on material condition of life in general and economic base in particular. Secondly, ruling class controls and regulates the production and distribution of ideas in such a way that the ideas in question best suits their interest of maintaining the system of class domination. Thirdly, the ruled classes, owing to lack of access to the control and production of ideas, are compelled to accept these ideas as their own voluntarily but in ignorance. Consequently, ideology in class society plays a significant role in the perpetuation and maintenance of class domination and exploitation.

For a more detailed explication of how ideology works in contemporary capitalism, Althusser's e Ideology and Ideological State Apparatus is instructive-in which he begins with the Marxist notion of essentiality of reproduction of conditions of production for the survival and continuity of any social formation. The reproduction of productive forces and the existing relation of production requires constant reproduction of labor power which is achieved and ensured not only through development of needed skills or know-how but also through inculcation of "rules of good behavior", which are to be "observed by every agent in the division of labour, according to the job he is 'destined' for" (Althusser, 1970). These includes "rules of morality, civic and professional conscience, which actually means rules of respect of socio-technical division of labour and ultimately the rules of order established by class domination" (Althusser, 1970). What we are taught in the school, therefore, are not just technical skills necessary to perform our duty but also those attitudes and behaviors that ensure "subjection to the ruling ideology or the mastery of its practice" (Althusser, 1970). Ideology is what "all agents of production, exploitation and repression ... must in one way or other be 'steeped' in order to perform their tasks 'conscientiously'- the tasks of the exploited (the proletarians), of the exploiters (the capitalists), of the exploiters' auxiliaries (the managers), or of the high priests of the ruling ideology (its 'functionaries'), etc." (Althusser, 1970).

Althusser also makes an elaborated attempt to show how reproduction of relation of production is ensured. For this, he introduces the concept of Ideological State Apparatus (ISA) which has to be distinguished from Repressive State Apparatus. These apparatuses differ from each other in terms of the way they function: Ideological State Apparatuses "function massively and predominantly by ideology, but they also function secondarily by repression" whereas Repressive State Apparatus "functions massively and predominantly by repression while functioning secondarily by ideology" (Althusser, 1970). The Ideological State Apparatuses, despite their diversity, are unified under "the ruling ideology, which is the ideology of ruling class" (Althusser, 1970). For Althusser, Ideological State Apparatus is so essential and important that "... no class can hold State power over a long period without at the same time exercising its hegemony over and in the State Ideological Apparatuses." In Althusser's analysis, the reproduction of relations of production is largely secured by ideological state apparatus "behind the shield provided by repressive State Apparatus," in which, "the role of ruling ideology is heavily concentrated ..." (Althusser, 1970). The ruling ideology, in this process, through "intermediation", ensures "a harmony between the repressive State apparatus and the Ideological State Apparatuses and between the different State Ideological Apparatuses" (Althusser, 1970).

Ideological State Apparatus includes a number of social institutions and apparatus such as religion, education, family, legal system, political system, trade union, communication and culture. With ample evidences and arguments, Althusser's concludes that educational 


\section{Foucault's Dismissal of Ideology: A Critique}

ideological apparatus "has been installed in the dominant position in the mature capitalist social formations ..." (Althusser, 1970). School-the educational ideological apparatus largely reproduces the relations of production "by an apprenticeship in a variety of knowhow wrapped up in the massive inculcation of the ideology of ruling class ..." (Althusser, 1970). The process of apprenticeship is disguised in a such a way that it appears that there is no such inculcation which it carries on. Althusser contends; "the mechanisms which produce this vital result ....are naturally covered up and concealed by a universally reigning ideology of the School, universally reigning because it is one of the most essential forms of ruling bourgeois ideology: and ideology which represents the School as neutral environment purged of ideology ..." (Althusser, 1970).

With a view to showing how ideology functions, Althusser proposes three theses. Firstly, "ideology represents the imaginary relationship of individuals to their real existence" Secondly, "ideology has material existence," which means "ideology always exists in apparatus and its practice, or practices." The conception of materiality of ideology means that ideology exists "in material ideological apparatus, prescribing material practices governed by a material ritual" and its practices "exist in material action of a subject acting in all consciousness according to his belief" (Althusser, 1970). It is to be noted here that the thesis of materiality of ideology provides a strong case to the idea that no social activity and practice are is ideology-free. On the contrary, social practices are governed by and express ideology which a subject or actor carries or approves of. Therefore, even if we adopt Foucault's method of investigating local everyday practices, ideology cannot be put aside. Ideology will always be present there in local practices including mutual relations among subjects, no matter what type they are and what they are intended for.

The third thesis states that "ideology interpellates individuals as subjects", which, to put simply, means: "there is no ideology except by the subject and for the subjects" (Althusser, 1970). The consequence of the deeper process of interpellation is that "the vast majority of (good) subjects work all right 'by themselves' i.e. by ideology. ...They recognize the existing state of affairs, that "it really is true that it is so and not otherwise" "and individual freely "accept his subjection ..." (Althusser, 1970). The interpellation thesis, thus, points out how individuals are manipulated to ensure their submission and subjection to the capitalist system of domination and make the submission appear free and voluntary. This being the case, how could a serious investigator disregards the role and functioning of ideology in system of domination or power relations?

Marcuse's One Dimensional Man shows how technical apparatus of production and distribution functions, in the most industrialized societies, to promote one dimensional thought and behavior through which control and domination is ensured. The advanced capitalist societies control individuals through creation of "false needs" and provision for their satisfaction which is effected through management of technical apparatuses. The progress made with the use of technology has its consequence that "it turns Reason into submission to the fact of life, and to the dynamic capability of producing more and bigger facts of the same sort of life" (Marcuse 1964, p. 11). The achievements of progress are so powerful and effective that they "defy ideological indictment as well as justification" and consequently "false consciousness of their rationality becomes the true consciousness" (Marcuse, 1964, p. 11). Marcuse remarks that "this absorption of ideology into reality does not, however, signify the "end of ideology"” (Marcuse 1964, p. 11). He strongly believes, on the contrary that "advanced industrial culture is more ideological than its predecessors, inasmuch as today the ideology is in process of production itself"' (Adorno as cited in 


\section{Foucault's Dismissal of Ideology: A Critique}

Marcuse, 1964, p. 11). Moreover, the present-day technologies and their use in several areas of life "carry with them prescribed attitudes, habits, certain intellectual and emotional reactions which bind the consumers more or less pleasantly to the producers and, through the latter, to the whole"" (Marcuse, 1964, p. 12). Moreover, "the products indoctrinate and manipulate; they promote a false consciousness which is immune against its falsehood. And as these beneficial products become available to more individuals in more social classes, the indoctrination they carry ceases to be publicity; it becomes a way of life. It is a good way of life - much better than before - and as a good way of life, it militates against qualitative change. Thus emerges a pattern of one-dimensional thought and behavior in which ideas, aspirations, and objectives that, by their content, transcend the established universe of discourse and action are either repelled or reduced to terms of this universe. They are redefined by the rationality of the given system and of its quantitative extension" (Marcuse, 1964, p. 12). It is not just that technologies and their products fulfils ideological functions by promoting and maintaining one dimensional thought but also that such thought is "systematically promoted by the makers of politics and their purveyors of mass information" whose "universe of discourse is populated by self-validating hypotheses which, incessantly and monopolistically repeated become hypnotic definition or dictation" (Marcuse, 1964, p. 14).

From above mentioned propositions and explanation, three important observations can be made which deflate some of Foucault's justifications for ruling out ideology. The first has to do with Foucault's dismissal of ideology for its alleged secondary position relative to its own infrastructure or economic base (Foucault, 1977). It is true that ideology, as a superstructural element, rests on economic base for its origin, but it is also equally true that, it, in turn, contributes to the maintenance and survival of the essence of domination based on and needed by the economic base. The generalizations made by Marx/Engels, Althusser and Marcuse, as we have discussed above, all affirm, beyond doubt, the reciprocity between economic base and superstructure. Foucault's seems to misunderstand superstructure as always being determined by the base but never having any substantial role, in turn. If the relationship had been one-way, such massive investment on production and propagation of ideology would not have been made in contemporary capitalist society.

Secondly, ideology in the contemporary capitalism is far more pervasive, encompassing and powerful owing, in large part, to the expansion of education, mass media, etc. and to bourgeoisies' monopolistic control over them. What makes production of ideology at present different from its predecessors is the kind of involvement of bourgeoisie in the process. The bourgeoisie is engaged in the process of production not only because the product, ideology is friendly to its ruling interest but also because that business of ideology is directly and immensely lucrative, such lucrativeness being facilitated by massive and monopolistic marketing. Moreover, ideology has become profoundly effective and rife because of its materiality as well as its considerable success in efficacious interpellation of subjects or individuals made possible, inter alia, through mass education and mass communication.

Thirdly, Foucault underscores the regime of truth to have a say on power relations arguing that "each society has its regime of truth, its 'general politics' of truth: that is, the types of discourse which it accepts and makes function as true ..." (Foucault, 1977, p. 131). To put it otherwise, in every society there is a system by which certain ideas are produced and presented to be accepted as true - which is ideology is all about. Therefore, Foucault's ruling out of ideology itself is ruled out. Foucault argues that when power is exercised through subtle mechanisms of "instruments for the formation and accumulation of knowledge- 


\section{Foucault's Dismissal of Ideology: A Critique}

methods of observation, techniques of registration, procedures for investigation and research, apparatus of control," which inevitably gives rise to and put into circulation "apparatuses of knowledge, which are not ideological constructs" (Foucault, 1976, p. 102). How could these apparatuses themselves and their product be non-ideological in any society with has certain kind of regime of truth at work? Can knowledge be ideology-free in a society in which 'truth' is produced by power and, in turn, serves the power? As a matter of fact, these apparatuses of knowledge are governed by certain ideology and are intended to produce and dissipate certain 'truth' to fit best to prevailing power.

\section{Conclusion}

Contrary to what Foucault claims, the notion of ideology constitutes an important component object of investigation in understanding system of power and domination in a capitalist social formation, or any social formation for that matter for two important reasons. The first reason is that the true-false distinction is necessary not only ontologically but also morally: ontologically, it is necessary for understanding the reality of a social formation and its attendant apparatuses; and morally, it is necessary for evaluating a social formation to see whether it is oppressive or not. It is important to note that in an oppressive social system, ideology obscures, distorts and falsifies reality and thereby present itself as truth that helps in maintaining and reinforcing the system. Without true-false distinction, our analysis of a system is no more than relativist account in which everything is both true and false. The second reason bears on the fact that though ideology has its origin in economic base, they are, undoubtedly, in reciprocal relationship. Consequently, ideology becomes invariably connected with economic base and plays important role in the latter's life and reproduction. Furthermore, ideology has become pervasive, all-encompassing, powerful instrument in the recent capitalist system due primarily to the expansion of education and mass communication largely controlled and manipulated by ruling classes to serve their interests best.

\section{References}

Althusser, L. (1970). Ideology and ideological state apparatus. http://www.marxists.org/ reference/archive/althusser/1970/ideology.htm

Detmer, D. (2003). Challenging postmodernism: Philosophy and the politics of truth. Humanity Books.

Engels, F. (1893). "Engels to Franz Mehring." http://marxists.org/ archive/marx/ works/ 1893/ letters/93_07_14.htm

Engels, F. (1894). "Engels to Borguis." http://marxists.org/ archive/marx/works/ 1894/ letters/ 94_01_25.htm

Foucault, M. (1972). "Intellectuals and power". In DF. Bouchard (Edt and translated) Language, Counter Memory, Practice: Selected Essays and Interviews. https://monoskop.org/ images/ 1/13/Foucault Michel Language Counter-Memory Practice_Selected_Essays_and_Interviews_1977.pdf

Foucault, M.(1977). “Truth and Power.” In C. Gordon (Ed.\& translated) Power/Knowledge: Selected interviews and other writings 1972-1977. Pantheon Books. 


\section{Foucault's Dismissal of Ideology: A Critique}

Foucault, Michel (1976). "Two Lectures." In C. Gordon (Ed. \& translated) Power/Knowledge: Selected interviews and other writings 1972-1977. Pantheon Books.

Kumar, C. (2005). "Foucault and rorty on truth and ideology: A Pragmatist view from the Left." Contemporary Pragmatism, Vol. 2 No. 1, 35-93. https://doi.org/10.1163/18758185$\underline{90000003}$

Marcuse, H. (1964). One dimensional man: Studies in the ideology of advanced industrial society. Beacon Press.

Marx, K and Engels, F. (1845). The German ideology. https://www.marxists.org/ archive/marx/works/1845/german-ideology/ch01a.htm\#5a4

Marx, K. (1859). "Preface to a contribution to the critique of political economy."

http://marxists.org/archive/marx/works/1859/critique-pol-economy/preface.htm 